\title{
Utilization of kitchen waste for the production of green thermoplastic polyhydroxybutyrate (PHB) by Cupriavidus necator CCGUG 52238
}

\author{
Farah Nadia Omar, Nor’Aini Abdul Rahman*, Halimatun Saadiah Hafid, Tabassum Mumtaz, \\ Phang Lai Yee and Mohd Ali Hassan
}

Department of Bioprocess Technology, Faculty of Biotechnology and Biomolecular Sciences, University Putra Malaysia, 43400 Serdang, Selangor, Malaysia.

Accepted 30 May, 2011

\begin{abstract}
Polyhydroxybutyrate (PHB) was produced by Cupriavidus necator CCGUG 52238 using organic acids from fermented kitchen waste. HPLC and nuclear magnetic resonance (NMR) analyses revealed that the acid comprised mainly of lactic and acetic acids. In shake flask culture, the lactic acid concentration above $10 \mathrm{~g} / \mathrm{L}$ inhibited both cell growth and polyhydroxybutyrate (PHB) production. The PHB production by the strain was achieved at the highest PHB content of $52.79 \%$ in batch fermentation using the kitchen-waste derived organic acids. The PHB yield and productivity were $0.38 \mathrm{~g} / \mathrm{g}$ and 0.065 $\mathrm{g} / \mathrm{L} / \mathrm{h}$, respectively. In fed-batch culture, about 4 -fold increase in PHB productivity $(0.242 \mathrm{~g} / \mathrm{L} / \mathrm{h})$ was achieved by applying intermittent feeding strategy.
\end{abstract}

Key words: Cupriavidus necator CCGUG 52238, kitchen waste, organic acids, polyhydroxybutyrate (PHB).

\section{INTRODUCTION}

The growing interest in the development of biodegradable plastics with properties similar to synthetic thermoplastics for the management of the existing plastic waste has directed the attention towards bacterial polyhydroxyalkanoates (PHA). The production of PHAs from agriculture, food processing waste materials is an attractive approach for not only effectively decreasing PHA production cost but also constructing a process for effective utilization of waste. Considering that PHA content and productivity are usually lower for bacteria grown in crude and inexpensive substrates, the development of efficient processes for the successful bioconversion remain a challenge to be pursued (Castilho et al., 2009).

In Peninsular Malaysia, generation of solid waste has increased from 17.000 tonnes per day in 2003 to 19,100 tonnes in 2005 with an average of 0.8 kilogram per capita per day. As of 2008, 23,000 tonnes of waste is produced each day in Malaysia, the generation in Kuala Lumpur

*Corresponding author. E-mail: nor_aini@biotech.upm.edu.my. Tel: +603 89466699. Fax: 60389430913. alone accounted to 3,000 tonnes per day. This will continue to increase in coming years and is expected to reach 30,000 tons per day in 2020 (GEC). The waste usually consists of $45 \%$ food waste, $24 \%$ plastic, $7 \%$ paper and $6 \%$ iron. In the current practice of waste management, approximately 95 to $97 \%$ of waste collected is taken to landfill for disposals and less than $5 \%$ of the waste is being recycled. However, considering the landfill shortage and contamination, government aimed to have $22 \%$ of the waste recycled by 2020 . While composting the kitchen refuse can recycle back the nutrients and energy to soil and reduce almost $50 \%$ of the waste; anaerobic digestion can also be applied to convert the food waste into organic acids which are preferable substrate for PHA production. Producing PHAs from kitchen waste can further reduce the inevitable usage of conventional plastics when biodegradable PHA as packaging material would take place in the market.

Owing to higher moisture content, kitchen waste is more suitable to undergo anaerobic digestion than thermo-chemical conversion. Significant research has been focused on using organic acids from fermented food wastes as raw materials for PHA production (Hafuka et 
Table 1. Characteristics of the kitchen waste used for PHB production.

\begin{tabular}{lc}
\hline Characteristics & Value \\
\hline $\mathrm{pH}$ & $4.0-5.5$ \\
$\mathrm{C} / \mathrm{N}$ & 30 \\
Total Kjeldahl nitrogen $(\%)$ & 1.2 \\
Ammonium Nitrogen $(\mathrm{mg} / \mathrm{L})$ & 286 \\
Total suspended solids $(\mathrm{g} / \mathrm{L})$ & 70.12 \\
\hline
\end{tabular}

al., 2011; Du and Yu, 2002; Du et al., 2004). However, food waste in developing countries is usually denser than in developed areas, and its composition is an indicator of the socio-economic situation of the population (Holmes, 1984). Nevertheless, the composition of organic acids in the fermented kitchen waste plays a major role in the overall performance of the PHA fermentation.

Considering the potential of using fermented kitchen waste as feedstocks for PHB production, this study was carried out to produce PHB in batch and fed batch fermentation by Cupriavidus necator CCGUG 52238, using mixture of lactic and acetic acids obtained from the kitchen waste.

\section{MATERIALS AND METHODS}

\section{Bacterial strain and cultural conditions}

C. necator CCGUG 52238, obtained from Culture Collection, University of Goteberg, Sweden was used throughout in this study. The wild type strain was grown on nutrient agar plate at $30^{\circ} \mathrm{C}$ for 24 h. The cells were then inoculated into a growth medium containing (in g/L) 8.0 nutrient broth, 5.0 yeast extract, 5.0 peptone, and 2.5 sodium lactate with $\mathrm{pH} 6.8$ to 7.0. The cells were cultivated under rotational agitation at $150 \mathrm{rpm}$ using incubator shaker (Lab Line, Environment Shaker) for $24 \mathrm{~h}$ at $30^{\circ} \mathrm{C}$ in $500 \mathrm{~mL}$ Erlenmeyer flasks with $200 \mathrm{~mL}$ of the working volume. The cells were harvested by centrifuging it aseptically at $4000 \mathrm{rpm}$ for $15 \mathrm{~min}$ and the supernatant was discarded. The pellet was then re-suspended in distilled water and was transferred into a $2 \mathrm{~L}$ bioreactor containing PHB production medium. The production medium used for PHB production contained (in $\mathrm{g} / \mathrm{L}$ ): $2 \mathrm{~K}_{2} \mathrm{HPO}_{4}, 6.7 \quad \mathrm{KH}_{2} \mathrm{PO}_{4}, 1.0$ $\left(\mathrm{NH}_{4}\right)_{2} \mathrm{SO}_{4}, 0.4 \mathrm{MgSO}_{4} .7 \mathrm{H}_{2} \mathrm{O}, 0.1 \mathrm{CaCl}_{2}, 0.04 \mathrm{FeSO}_{4}, 2.0$ Lactic acid and $1.0 \mathrm{~mL}$ of trace elements (Hassan et al., 1997a). The $\mathrm{pH}$ of the production medium was controlled at 6.8 to 7.0 using $2 \mathrm{M}$ $\mathrm{H}_{2} \mathrm{SO}_{4}$ and $2 \mathrm{M} \mathrm{NaOH}$.

\section{Substrate for PHB fermentation}

Kitchen waste was collected from several food courts in UPM, Serdang, Malaysia. Acidogenic fermentation of kitchen waste was carried out to produce organic acids until 8 th day at $37^{\circ} \mathrm{C}$ with initial $\mathrm{pH}$ adjusted to 7.0 as reported by Omar et al. (2009). The separation of the solids from the fermentation broth was achieved by spinning the slurry at $10,000 \mathrm{rpm}$ in $50 \mathrm{~mL}$ centrifuge tube for 30 min. The pellets were discarded and organic acids in the supernatant were concentrated to ten-folds using rotary vacuum evaporator (Eyela) at $70^{\circ} \mathrm{C}$. The final concentration of organic acids after evaporation process ranged from 200 to $280 \mathrm{~g} / \mathrm{L}$. The samples were then kept at $-20^{\circ} \mathrm{C}$ prior to use as carbon substrate for $\mathrm{PHB}$ production.

\section{PHB biosynthesis by C. necator CCGUG 52238}

\section{Shake-flask experiments}

In order to examine the potential of the organic acids from kitchen waste, a series of batch experiments were conducted to examine the effect of $5,10,15$ and $20 \mathrm{~g} / \mathrm{L}$ of organic acid mixtures on the PHA production. The flasks containing mineral media were inoculated with $24 \mathrm{~h}$ old culture of C. necator CCGUG 52238 and were incubated at $30^{\circ} \mathrm{C}, 200 \mathrm{rpm}$ for $24 \mathrm{~h}$. The cells were harvested and examined for biomass and PHB concentration. Parallel set of experiments were conducted using technical grade organic acids in the range of 5 to $20 \mathrm{~g} / \mathrm{L}$ for comparison.

\section{PHB fermentation in bioreactors}

Batch and fed batch fermentations were performed in a $2 \mathrm{~L}$ bioreactor (Biostat ${ }^{\circledR}$ MD B.Braun Biotechnology International) with the working volume of $1 \mathrm{~L}$. Agitation was achieved by six-blade rushton type impeller and $\mathrm{pH}$ was maintained at 7.0 by using $2 \mathrm{~N}$ $\mathrm{NaOH}$ and $2 \mathrm{~N} \mathrm{H}_{2} \mathrm{SO}_{4}$. The dissolved oxygen level (DO) was maintained above $30 \%$ air saturation by sequential cascade control of fixed air flow and variable rotation speed. Silicone based antifoam $(10 \% \mathrm{v} / \mathrm{v})$ was used to control foaming and temperature was maintained at $30^{\circ} \mathrm{C}$.

Fed-batch studies were carried out in $7 \mathrm{~L}$ bioreactor (Bioengineering AG, Switzerland) with $5 \mathrm{~L}$ of working volume in order to improve the PHB production and increase the productivity from batch studies. The initial batch fermentation contained $10 \mathrm{~g} / \mathrm{L}$ of organic acids from kitchen waste and after $10 \mathrm{~h}$ of fermentation; concentrated acid solution (200 to $280 \mathrm{~g} / \mathrm{L}$ ) was added intermittently to keep the residual acid concentration in the reactor below $3 \mathrm{~g} / \mathrm{L}$ (Figure 4). The organic acids were sterilized and used without any nutrient supplementation. Samples were withdrawn every $5 \mathrm{~h}$ to examine biomass, residual organic acid and PHB concentration. The fermentation was terminated at $40 \mathrm{~h}$.

\section{Analytical procedures}

Organic acid in the broth and the PHB content in the cell mass was measured by using HPLC (SPD-10A, UV-Vis Detector; LC-10 AS Liquid Chromatograph Shimadzu) with HPLC Acid Analysis Column, $300 \times 7.8 \mathrm{~mm}$ (Aminex HPX-87H Ion Exclusion Column, Bio-Rad Laboratories) as described previously (Hassan et al., 1997b). Cell dry weight was measured gravimetrically. The organic acid composition in the kitchen waste organic acid was further verified using nuclear magnetic resonance (NMR) analysis. The 400 $\mathrm{MHz}{ }^{1} \mathrm{H}$ NMR spectra recorded at $27^{\circ} \mathrm{C}$ on a $\mathrm{CDCl}_{3}$ solution. Peak areas were determined by spectrometer integration by using tetramethylsilane (TMS) as an internal reference.

\section{RESULTS AND DISCUSSION}

\section{Characteristics of substrate for PHB fermentation}

The characteristics of the kitchen waste used in this study are shown in Table 1. The kitchen waste had an acidic $\mathrm{pH}$ range of 4.5 to 5.5 . The range is similar to the 


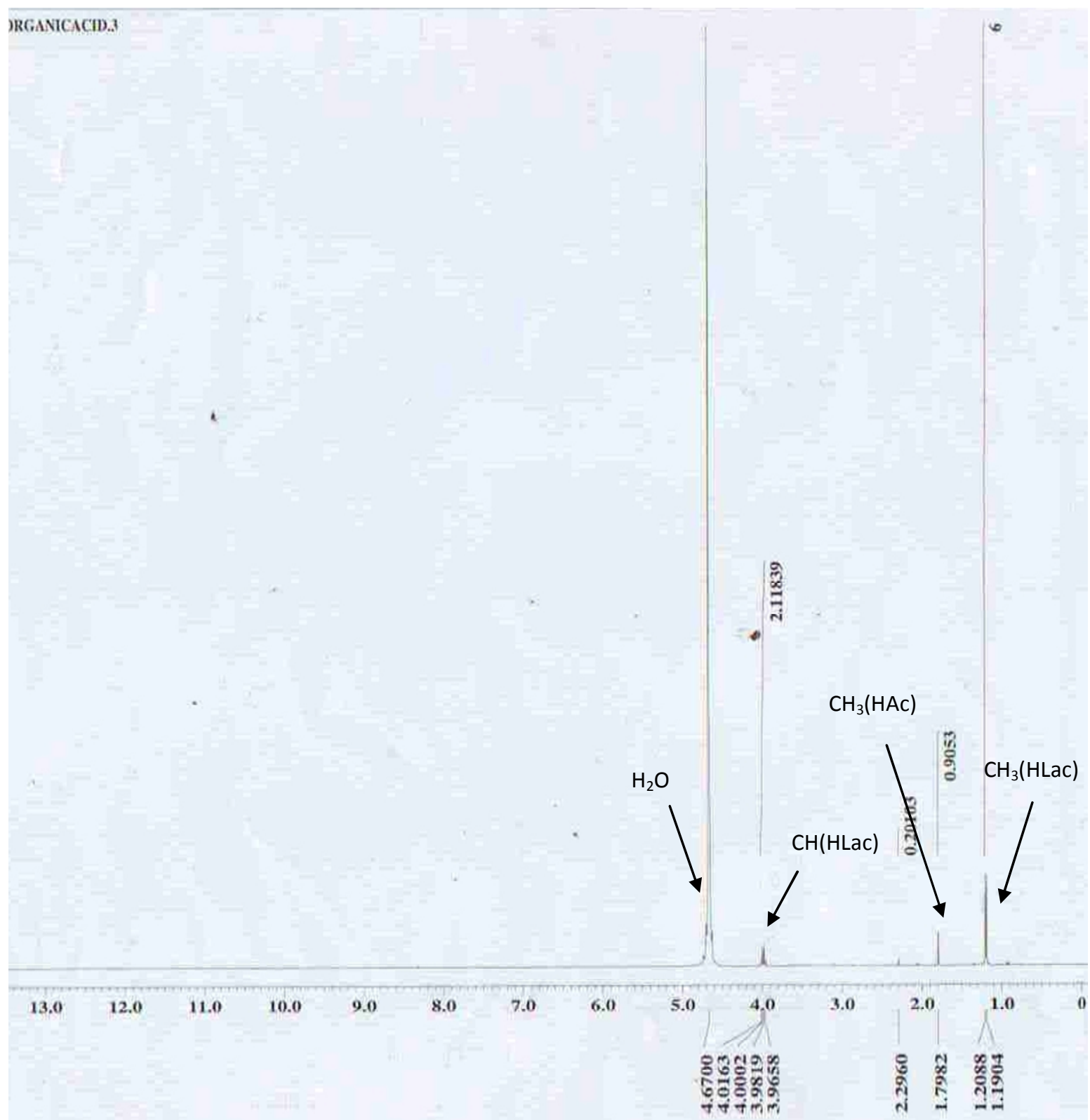

Figure 1. The $400 \mathrm{MHz}{ }^{1} \mathrm{H}$ NMR spectra of organic acids produced from fermented kitchen waste used as PHB substrate in this study. HLac- Lactic acid, HAc- Acetic acid.

reported value of 4.6 and 5.1 by Kim et al. (2004) and Stabnikova et al. (2008), respectively. This is due to the action of indigenous microbes in the fermented kitchen wastes that break down the complex organic materials into organic acids and contributed to the acidity of the solution. The concentrated organic acid was brown in colour and was consisted of $210 \mathrm{~g} / \mathrm{L}$ lactic acid and 13.9 $\mathrm{g} / \mathrm{L}$ acetic acid. As shown in Table 1, the organic acids contained $1.2 \%$ of total Kjeldahl nitrogen (TKN) and about $286 \mathrm{mg} / \mathrm{L}$ of ammonical nitrogen. This value is about three times lower than that reported by Zhang et al. (2007) where total $\mathrm{N}$ was $3.16 \%$ and ammonical nitrogen content was $973 \mathrm{mg} / \mathrm{L}$. Comparatively lower fraction
$(20 \%)$ of protein-rich materials in the original food waste as reported by Hafid et al. (2010) may be responsible for the lower amount of ammonium nitrogen in our sample. The $\mathrm{C} / \mathrm{N}$ ratio in our sample was found to be 30 whereas studies carried out by Malakahmad et al. (2008) showed slightly higher $\mathrm{C} / \mathrm{N}$ ratio (38.2). However, in both cases, the higher $\mathrm{C} / \mathrm{N}$ ratio reflects the lower nitrogen content in the kitchen waste which makes this substrate suitable for PHA production.

Figure 1 shows the NMR spectra of concentrated organic acids from kitchen waste. The peak assignments were performed on the basis of chemical shift comparisons with data in the literature (Figueiredo et al., 
Table 2. Comparison of shake flasks fermentation for PHB production utilizing organic acids from kitchen wastes and technical grade organic acids at different initial concentrations.

\begin{tabular}{lcccccccc}
\hline & \multicolumn{4}{c}{ Technical grade organic acids $\mathbf{~ ( g / L ) ~}$} & \multicolumn{4}{c}{ Kitchen waste organic acids (g/L) } \\
\hline Initial concentrations & 5 & 10 & 15 & 20 & 5 & 10 & 15 & 20 \\
DCW (g/L) & 2.2 & 3.1 & 1.5 & 0.7 & 2.6 & 2.9 & 1.2 & 0.79 \\
PHB (g/L) & 0.682 & 1.364 & 0.18 & 0.07 & 0.91 & 1.218 & 0.12 & 0.09 \\
PHB (\%) & 31 & 44 & 12 & 10 & 35 & 42 & 10 & 11 \\
Productivity (g/ L/h) & 0.028 & 0.057 & 0.007 & 0.003 & 0.038 & 0.051 & 0.005 & 0.004 \\
\hline
\end{tabular}

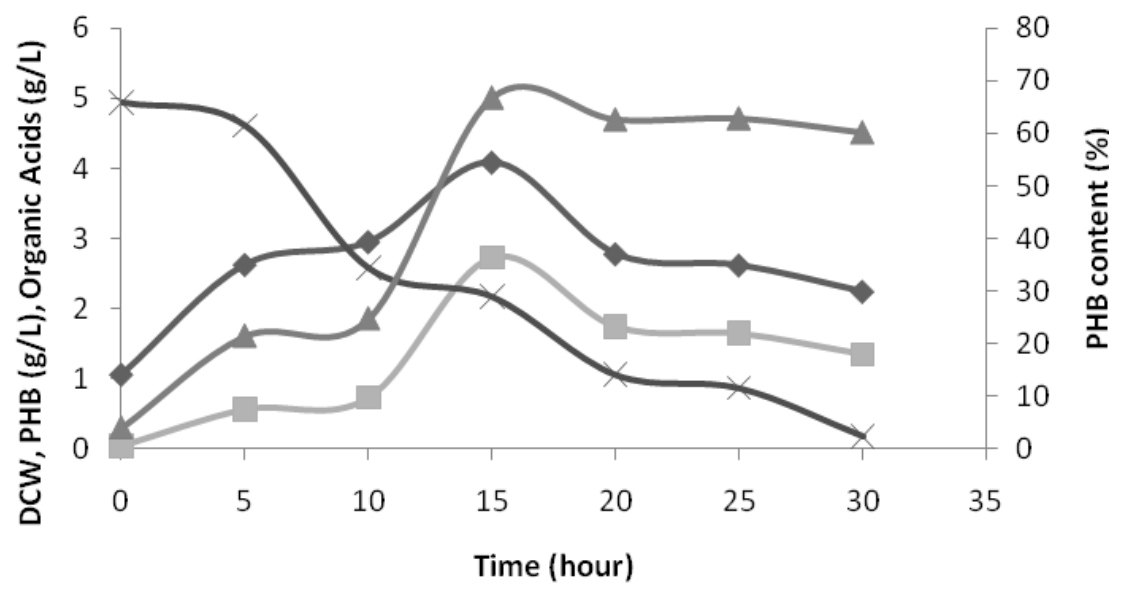

$\leadsto$ DCW $(\mathrm{g} / \mathrm{L})-\mathrm{PHB}(\mathrm{g} / \mathrm{L}) \smile$ Organic Acids $(\mathrm{g} / \mathrm{L}) \multimap \mathrm{PHB}$ content $(\%)$

Figure 2. Time course of PHB production by Cupriavidus necator CCUG 52238 using $5 \mathrm{~g} / \mathrm{L}$ technical grade organic acid in batch culture.

2006; Espartero et al., 1996). The most intense signals were assigned to $\mathrm{CH}(4.02 \mathrm{ppm})$ and $\mathrm{CH}_{3}(1.21 \mathrm{ppm})$ of L-lactic acid, while peak assigned to $\mathrm{CH}_{3}(1.79 \mathrm{ppm})$ was for acetic acid. Spectral analysis revealed that the predominant organic acid species in the fermented kitchen waste in this study were lactic acid and acetic acid (Figure 1).

\section{PHB biosynthesis by C. necator CCGUG 52238}

\section{Shake-flask experiments}

The biomass concentration, PHB concentration, PHB content and productivity using different concentration of organic acid in shake flask experiments are shown in Table 2. It can be seen that the concentration of cells decreased as the initial concentration of lactic acid in the medium increased from $10 \mathrm{~g} / \mathrm{L}$ until $20 \mathrm{~g} / \mathrm{L}$. Similar trend was observed by Tanaka et al. (1993) in shake flask cultures of Alcaligenes eutrophus ATCC 17697 using mixture of lactic acid and acetic acid from xylose. More interestingly, the inhibitory effect of these acids to the cells of C. necator CCGUG 52238 were found to be similar regardless of their origin (either kitchen waste derived or technical grade) under identical culture conditions and acid concentrations. In both cases, concentration of $10 \mathrm{~g} / \mathrm{L}$ of organic acids was found to be suitable for the batch production of PHB by $C$. necator CCGUG 52238 in the shake flask condition. The higher concentration (above $10 \mathrm{~g} / \mathrm{L}$ ) reduced the cell growth as well as the PHB production probably due to the inhibitory effect of lactic acid to the cells. Hence, it was important to keep the concentration of lactic acid at low level throughout the cultivation process to obtain optimum PHB production in batch culture. Since shake flask experiments could not provide the ideal condition of mixing and $\mathrm{pH}$ control, further studies were carried out in $2 \mathrm{~L}$ bioreactor.

\section{Batch cultivation in bioreactor for PHB production}

The time course of PHB accumulation in $\mathrm{pH}$-controlled batch cultivation of C. necator CCUG 52238 using $5 \mathrm{~g} / \mathrm{L}$ technical grade organic acid as carbon source is shown in Figure 2. A sharp decline in the concentration of organic acid was noticed in the first $10 \mathrm{~h}$ after which the 


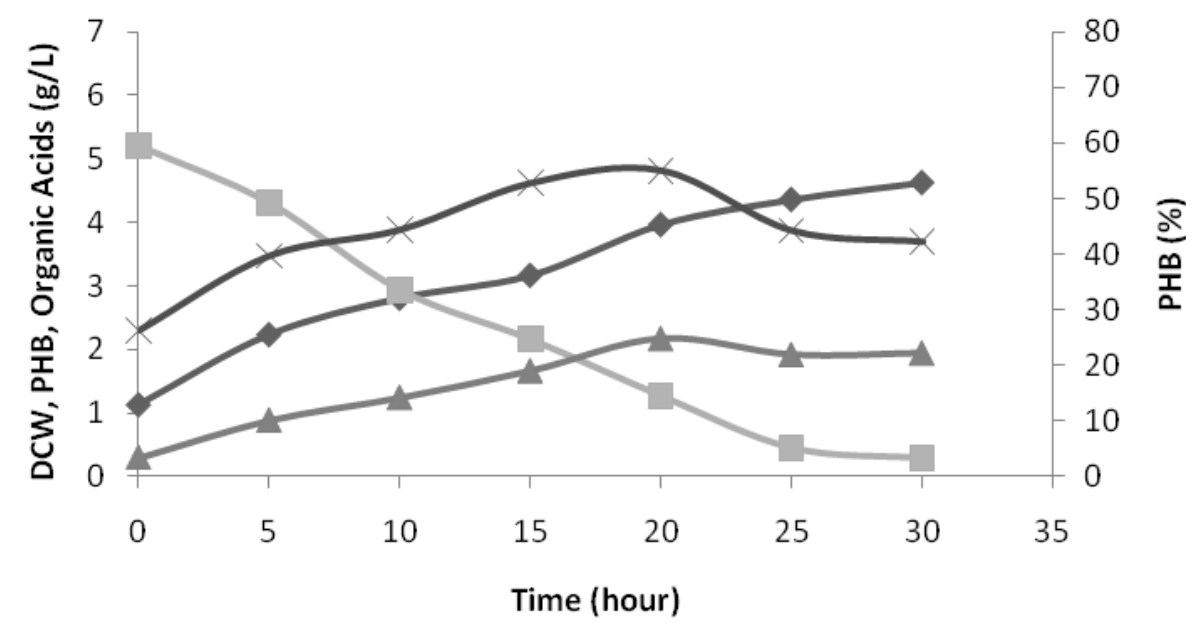

$\leadsto$ DCW $(\mathrm{g} / \mathrm{L}) \multimap$ Organic Acids $(\mathrm{g} / \mathrm{L}) \multimap \mathrm{PHB}(\mathrm{g} / \mathrm{L}) \multimap \mathrm{PHB}(\%)$

Figure 3. Time course of PHB production by Cupriavidus necator CCUG 52238 using 5 $\mathrm{g} / \mathrm{L}$ organic acids from kitchen waste in batch culture.

substrate was gradually consumed and completely depleted within $30 \mathrm{~h}$ of incubation. The cells and PHB concentration started to increase gradually and reached maximum value at $15 \mathrm{~h}$ of cultivation. The final cell concentration reached up to $2.25 \mathrm{~g} / \mathrm{L}$ at 30 th $\mathrm{h}$. The highest production of PHB obtained was about $2.73 \mathrm{~g} / \mathrm{L}$ with $4.09 \mathrm{~g} / \mathrm{L}$ of cell dry weight at $15 \mathrm{~h}$ of incubation corresponding to $0.47 \mathrm{~g} / \mathrm{g}$ of PHB yield and $0.53 \mathrm{~g} / \mathrm{g}$ of cell yield.

When organic acids from kitchen waste was used as sole carbon source, on the other hand, the biomass and PHB concentration reached 4.6 and $1.9 \mathrm{~g} / \mathrm{L}$, respectively at the end of fermentation (Figure 3). Cell and PHB yield were 0.65 and $0.38 \mathrm{~g} / \mathrm{g}$ respectively. The PHB content was $60 \%$ with $\mathrm{PHB}$ productivity of $0.11 \mathrm{~g} / \mathrm{L} / \mathrm{h}$.

It is interesting to note that in the fermentation with technical organic acids, maximum biomass was achieved at earlier stage, that is, $15 \mathrm{~h}$ of fermentation after which the cell dry weight as well PHB concentration were reduced probably due to the complete exhaustion of nitrogen source in the medium. In contrast, in the case of kitchen waste-derived organic acids, the cell mass increased gradually until $30 \mathrm{~h}$ at the end of fermentation. PHB also started to accumulate gradually and reached $55 \%$ by weight at $20 \mathrm{~h}$ after which the concentration remained almost same. The biomass continued to increase until end of the cultivation, whereas PHB biosynthesis slowed down. The residual acid in the broth was below 1 $\mathrm{g} / \mathrm{L}$ at this moment and the depletion of carbon sources may result into re-utilization of PHB inside the cell.

Generally, technical grade organic acids (98\% purity) give higher values for most parameters measured including PHB yield and productivity whereas the organic acids from kitchen waste may contain dissolved solids or other impurities. Zhang et al. (2008) stated that the nonsterile kitchen wastes fermentation system gave low purity due to the complex natural microbial composition. However, in this study, prior to fermentation, organic acids recovered from fermented kitchen waste was concentrated using rotary evaporator and was sterilized at $121^{\circ} \mathrm{C}$ for $15 \mathrm{~min}$ in the autoclave. Compared to technical grade organic acids, batch studies using organic acid from kitchen waste showed superior results in $C$. necator probably due to the additional components in the acid that improve the fermentation performance. Moreover, the presence of nitrogen may act as a buffering agent in the culture media and provides optimal condition for PHB fermentation. The existence of characteristic peaks of acetic acid and lactic acid in NMR spectra further confirmed that only acetic acid and lactic acid were present in the organic acid from fermented kitchen waste (Figure 1).

\section{Fed-batch cultivation in bioreactor for PHB production}

In order to achieve higher cell density and higher productivity of PHB from that obtained in batch production, fed batch fermentation in $7 \mathrm{~L}$ bioreactor was carried out with $5 \mathrm{~L}$ of working volume using organic acids from kitchen wastes. A typical time course for growth and PHB accumulation of $C$. necator CCGUG 52238 in fermentation process is shown in Figure 4. The cell and PHB concentration at $25 \mathrm{~h}$ were 14.44 and 12.20 $\mathrm{g} / \mathrm{L}$, respectively, resulting in a PHB content of $84.54 \%$. The yield of cells $\left(\mathrm{Y}_{\mathrm{x} / \mathrm{s}}\right)$ and PHB $\left(\mathrm{Y}_{\mathrm{p} / \mathrm{s}}\right)$ were 1.08 and 0.79 $\mathrm{g} / \mathrm{g}$, respectively. At the end of the fermentation, about 


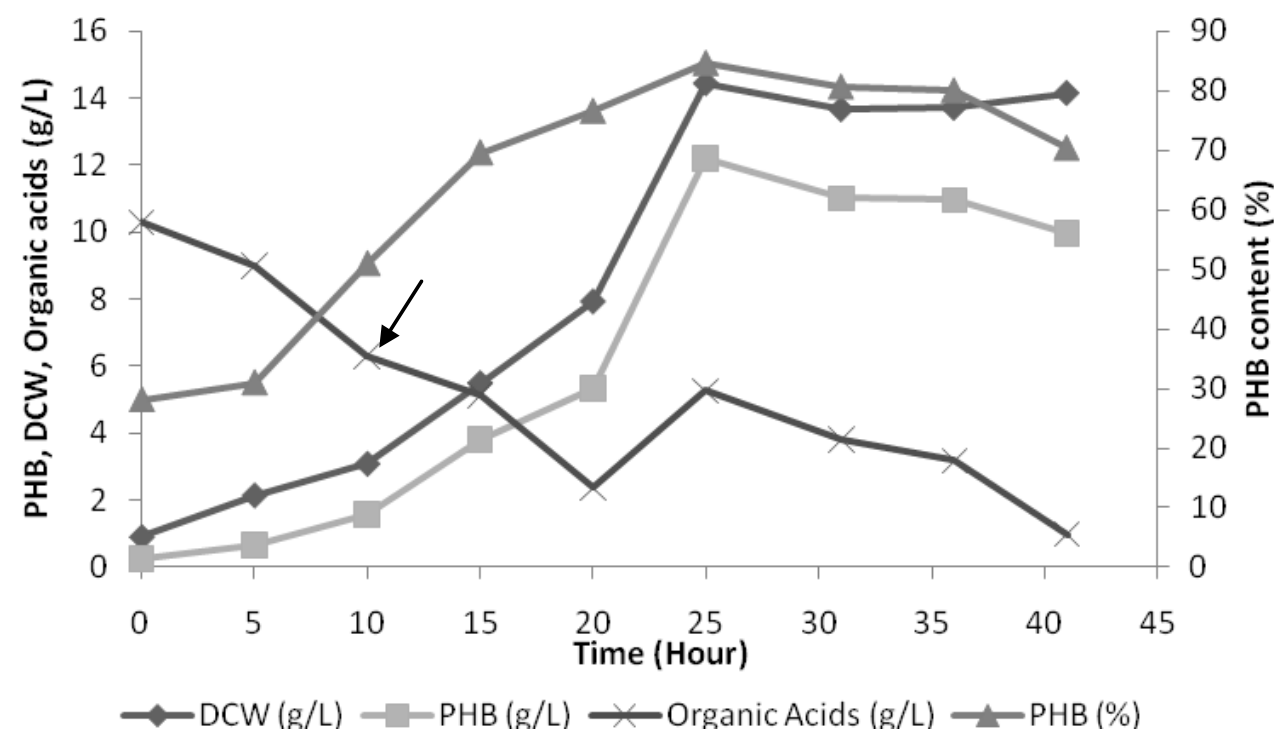

Figure 4. Time course of PHB production by Cupriavidus necator CCUG 52238 using organic acids from kitchen waste by fed-batch culture in $7 \mathrm{~L}$ bioreactor (Arrow indicates the initiation of feeding).

$0.98 \mathrm{~g} / \mathrm{L}$ of organic acids remained in the fermentation broth. Substrate utilization rate and $\mathrm{PHB}$ production rate were 0.3 and $0.24 \mathrm{~g} / \mathrm{L} / \mathrm{h}$, respectively. Du et al. (2004) also reported PHB productivity of $0.23 \mathrm{~g} / \mathrm{L} / \mathrm{h}$ by $\mathrm{C}$. necator using short chain fatty acids from fermented food scraps.

In this study, the carbon to nitrogen $(\mathrm{C} / \mathrm{N})$ ratio after 10 $\mathrm{h}$ was changed to 30 in order to promote PHB biosynthesis. Interestingly, the organic acid from kitchen wastes used in this study had $\mathrm{C} / \mathrm{N} \mathrm{30}$, so the requirement for additional nitrogen source was minimized. The DO was maintained at $30 \%$ giving a little pressure for the cells to accumulate the PHB intracellularly. It is well known that when $C$. necator is cultivated under oxidative growth conditions, the biopolymer synthesis can be enhanced (Jung and Lee, 2000).

In order to maintain the cell growth and also to keep the PHB accumulated in the cells, residual concentration of organic acids in the broth need to be kept at lower concentration. While, $\mathrm{pH}$-stat feeding has been employed by most of the researchers to feed short chain fatty acids (Kobayashi et al., 2000; Sugimoto et al., 1999; Tsuge et al., 1999), for lactic acid and a mixture of lactic and acetic acids, feeding at different time intervals that is intermittent feeding strategy has been found to be more suitable (Tsuge et al., 2001; Linko et al., 1993; Tanaka et al., 1993). Very recently, Hafuka et al. (2011) reported high PHB content $(\sim 87 \%)$ by continuous feeding of filtered fermented food wastes in $C$. necator. However, the biomass and PHB production rate was quite low as compared to others. In this study, attempt to produce PHB by pH-stat feeding strategy was not successful. However, by applying intermittent feeding strategy, similar PHB productivity $(0.24 \mathrm{~g} / \mathrm{L} / \mathrm{h})$ and PHB content $(\sim 86 \%)$ as reported in the literature were obtained.

\section{Conclusions}

In this study, fed-batch fermentation resulted into 5-fold increase in the PHB production as compared to batch production. Accumulation of PHB as high as $84.54 \% \mathrm{w} / \mathrm{w}$ in the cells of $C$. necator CGUG 52238 was achieved by intermittent feeding of lactic and acetic acid mixture ( $230 \mathrm{~g} / \mathrm{L}, 15: 1$ ratio) obtained from fermented kitchen waste. This high accumulation is favourable for costeffective recovery and can be compared with the glucose fermentation. The results also demonstrated that the organic acids from kitchen waste can be utilized as a suitable, cheap substrate for PHB production thereby increasing the possibility of recycling the major portion of food waste into biodegradable green plastics.

\section{ACKNOWLEDGEMENTS}

The authors would like to acknowledge the technical and financial support received from Ministry of Science, Innovation and Technology (MOSTI), Malaysia. Special thanks are made to Professor Ir. Dr. Jailiani Bin Salihon, University Malaysia Pahang (UMP), Malaysia for kindly providing C. necator CGUG 52238 culture used in this study.

\section{REFERENCES}

Castilho LR, Mitchell DA, Freire DMG (2009). Production of polyhydroxyalkanoates (PHAs) from waste materials and by-products by submerged and solid-state fermentation. Bioresource Technol., 100: 5996-6009.

Du G, Lilian XL, Yu J (2004). High-Efficiency Production of Bioplastics from Biodegradable Organic Solids. J. Polymers Environ., 12(2): 8994. 
Du G, Yu J (2002). Green technology for conversion of food scraps to biodegradable thermoplastic polyhydroxyalkanoates. Environ. Sci. Technol., 36: 5511-5516

Espartero JL, Rashkov I, Li SM I, Manolova N, Vert M (1996). NMR Analysis of Low Molecular Weight Poly(lactic acid)s. Macromology, 29: 3535-3539.

Figueiredo IM, Pereira, NR, Efraim P, Garciäa NHP, Rodrigues NR, Marsaioli ANJr, Marsaioli AJ (2006). ${ }^{1} \mathrm{H}$ NMR, a Rapid Method to Monitor Organic Acids during Cupuassu (Theobroma grandiflorum Spreng) Processing. J. Agric. Food Chem., 54: 4102-4106.

Hafid HS, Nor'Aini AR, Omar FN, Phang LY, Suraini AA, Hassan MA (2010). A Comparative Study of Organic Acids Production from Kitchen Waste and Simulated Kitchen Waste. Australian J. Basic Appl.Sc., 4(4): 639-645.

Hafuka A, Sakaida K, Satoh H, Takahashi M, Watanabe Y, Okabe S (2011). Effect of feeding regimens on polyhydroxybutyrate production from food wastes by Cupriavidus necator. Bioresource Technol., 102(3): 3551-3553.

Hassan MA, Shirai Y, Kusubayashi N, Karim MIA, Nakanishi K, Hashimoto K (1997b). The production of polyhydroxyalkanoate from anaerobically treated palm oil mill effluent by Rhodobacter spheroides. J. Ferment. Bioeng., 83(5): 485-488.

Hassan MA, Shirai Y, Umeki H, Yamazumi H, Jin S, Yamamoto S, Karim MIA, Nakanishi I, Hashimoto K (1997a). Acetic acid separation from anaerobically treated palm oil mill effluent by ion exchange resins for the production of polyhydroxyalkanoate by Alcaligenes eutrophus. Biosci. Biotech. Biochem., 61: 1465-1468.

Holmes JR (1984). Managing Solid Wastes in Developing Countries, John Wiley and Sons, Chichester, UK.

Jung YM, Lee YH (2000). Utilization of oxidative pressure for enhanced production of poly- $\beta$-hydroxybutyrate and poly-3-hydroxybutyrate-3hydroxyvalerate in Ralstonia eutropha. J. Biosci. Bioeng., 90(3): 266270.

Kim SH, Han SK, Shin HS (2004). Feasibility of biohydrogen production by anaerobic co-digestion of food waste and sewage sludge. Int. J. Hydrogen Energy, 29: 1607-1616.

Kobayashi G, Tanaka K, Itoh H, Tsuge T, Sonomoto K, Ishizaki A (2000). Fermentative production of $\mathrm{P}(3 \mathrm{HB}-\mathrm{co}-3 \mathrm{HV})$ from propionic acid by Alcaligenes eutrophus in fed-batch culture with $\mathrm{pH}$-stat continuous substrate feeding method". Biotechnol. Lett., 22: 10671069.
Linko S, Vaheri H, Seppala J (1993). Production of poly- $\beta$ hydroxybutyraye on lactic acid by Alcaligenes eutrohus $\mathrm{H} 16$ in a $3 \mathrm{~L}$ bioreactor. Enzyme Microbiol. Technol., 15: 401-406.

Malakahmad AD, Basri A, Ezlin N, Shahrom MZ (2008). Overview on the development of anaerobic digestion for kitchen waste in Malaysia. In: Sustainable Environmental Technology and Sanitation for Tropical Region, 18-19.11.2008, Surabaya, Indonesia.

Omar FN, Nor'Aini AR, Hafid HS, Phang LY, Hassan MA (2009). Separation and recovery of organic acids from fermented kitchen wastes by an integrated process. Afr. J. Biotechnol., 8(21): 58075813.

Stabnikova O, Xue-Yan L, Jing YW (2008). Anaerobic digestion of food waste in a hybrid anaerobic solid-liquid system with leachate recirculation in an acidogenic reactor. Biochem. Eng. J., 41: 198-201.

Sugimoto T, Tsuge T, Tanaka K, Ishizaki A (1999). Control of acetic acid concentration by $\mathrm{pH}$-stat continuous substrate feeding in heterotrophic culture phase of two-stage cultivation of Alcaligenes eutrophus for production of $\mathrm{P}(3 \mathrm{HB})$ from $\mathrm{CO}_{2}, \mathrm{H}_{2}$ and $\mathrm{O}_{2}$ under nonexplosive condition. Biotechnol. Bioeng., 62: 625-631.

Tanaka K, Katamune K, Ishizaki A (1993). Fermentative production of poly- $\beta$-hydroxybutyric acid from xylose by a two-stage culture method employing Lactococcus lactis $1 \mathrm{O}-1$ and Alcaligenes eutrophus. Biotechnol. Lett., 15(2): 1217-1222.

Tsuge T, Tanaka K, Ishizaki A (2001). Development of a novel method for feeding a mixture of L-lactic acid and acetic acid in fed batch culture of Ralstonia eutropha for poly-D-3-hydroxybutyrate production. J. Biosci. Bioeng., 91(6): 545-550.

Tsuge T, Tanaka K, Shimoda M, Ishizaki A (1999). Optimization of Llactic acid feeding for the production of poly-D- 3-hydroxybutyric acid by Alcaligenes eutrophus in fed-batch culture. J. Biosci. Bioeng., 88: 404-409.

Zhang B, Pin-jing H, Ning-fang $Y$, Li-ming S (2008). Enhanced isomer purity of lactic acid from the non-sterile fermentation of kitchen wastes. Bioresource Technol., 99: 855-862.

Zhang R, El-Mashad HM, Hartman K, Wang F, Liu G, Choate C, Gamble P (2007). Characterization of food waste as feedstock for anaerobic digestion. Bioresource Technol., 98: 929-935. 